\title{
Hawthorne and Republicanism: The Scarlet Letterand the writer's Contextual Motivations
}

\author{
Bamshad Hekmatshoar Tabari \\ Shahid Chamran University of Ahvaz \\ (corresponding author)
}

Mohammad Javad Mohammadi

Fraydan Branch, Islamic Azad University, Isfahan, Iran M.mohammadi1377@gmail.com

\section{Doi:10.5901/mjss.2013.v4n6p347}

\begin{abstract}
Much has been said and written aboutNathaniel Hawthorne'sThe Scarlet Letter, its thematic significance, symbolism, archaic language and religious overtones. Yet it seems that one important thing has been ignored in the way of the analysis of this work and this isthe clues inside the story itself which will be significant when read in relation with Hawthorn's personal life, and the collective unconsciousness of the society in which he has been brought up. To be precise, the following article is an attempt to trace the contextual motivations of Hawthorn in writing The Scarlet Letter.
\end{abstract}

\author{
"A Writer of Story Books! \\ What Kind of Business in Life- \\ What Kind of Glorifying God,"
}

The sentenceabove is quoted from "the Custom House", the semi-autobiographical section, preliminary to Hawthorne'sThe Scarlet Letter. One may find such a section, a deficit or a just an old-fashioned authorialstrategy to provide enough suspense for reading. But many critics take this section as of more significance and try to investigate its relation-its autobiographical evidence- with the contextual motivations that have given Hawthorne the food for thought and consequently enough reason for the writing of The Scarlet Letter. This short paperintends to analyze in detail "republicanism" (Moss 1), as one of those motivesand tries to express the viewpoints of Hawthorne in this case.

Looking at the matter of republicanism and its foundations in America, it is rather to be labeled as an eighteenth century phenomena, and its history goes back to the establishment of New England - George Washington becoming its first president in 1789-but by checking the histories, one finds that it is not till 1854 that the first American republican party is settled. In fact by 1854 the society of America was yet to bear the traces of sixteenth century Puritanism and in practice the idea of liberty had lost its color in the eyes of people. It was in such a context that writers like Hawthorne with political concerns started their work and tried to bring reformations.DeborabGossman in his article focuses on this matter and asserts that republicanism is the major concern of Hawthorne in The Scarlet Letter, and believes that in- order to investigate the issue, Hawthorne has a kind of pathological treatmentand chooses the societal basis of American civil life as the context to be studied- a sixteenth century Puritan Colony at Boston, Massachusetts(59). He adds that Hawthorne's question the utopian viewpoints of puritans and by that he announces even his feeling of guilt for his puritan ancestry (60). In fact, it is this writer's obsession with the ruin that Puritanism has brought to people of America and his political struggle for expiatingthatcauses him to beexpelled from his job and consequently to be obliged to work in a custom house for several years. Here at this point another important thing is worthy to be mentioned- that would reveal another motif for Hawthorne in writing that novel. In an article,Reynold asserts the fact that by mid-nineteenth century, Europe was facing a change in matter of politics- England had become a great power, Spanish and Portuguese colonizerswerein flee, Napoleon warshad broken out and Italy was dealing with a bloody liberal uproar that finally lead to thebafflement of Holly Roman Empire. He believes that all those European struggles with liberal concern had in fact been too much interesting for the people of New Englandwho were thirsty for the establishment of a stable republic (48). So it is natural thatHawthorne had been affectedby those movements and his writing career was under the influence of such 
viewpoints- especially his writing of The Scarlet Letterwhich is contemporaneous with those movements. These motifs for Hawthorne's writing of The Scarlet Letterwill be more reliable if a third one is added to them: Transcendentalism in America and its relation with republicanism.

It was just mentioned that Hawthorne chose a sixteenth century Puritan Colony as the context for his novel, why? And how he is to insert his political concerns metaphorically in a work of such quality that many critics believe to be his master piece? One key term- as introduced above- is transcendentalism which is very helpful in elaborating the matter. Transcendentalism is the American counterpart of English Romanticism and shares with it the liberation of emotions and imagination while opposing the dogmas of neo-classicliterature and worldview. But there is one sharp contrast between these two movements and that is the secularization attached to Romanticism- while the religious hue of Transcendentalism is of its major characteristics. Unlike Romanticism, Transcendentalism believes strongly in divine God as the source of the emanation of truth and order and claims all man's corruption- an American citizen in specific- to be the result of wrong civil forces and restrict laws of religion during centuries. It believes sin to be brought about by what-by wrong- civil religious apparatus preach againsthuman nature andsees the remedyin returning to nature in all its rawness and virginity. By adding up what was said here, it becomes clear that why Hawthorne is to choose that context for his writing of The Scarlet Letter: He strongly believes in Transcendentalism and republicanism and as a reaction against the treatment of his forefathers wants to preach a freedom in light of the liberation of the nature oppressed.To do that, naturally he has to go back in time for reaching a kind of verisimilitude, and a plot for representing characters as the victims of such a restriction-Hester Prynne, Pearl and Arthur Dimmesdale.

The second matter put in question should yet be answered? How is Hawthorne able to reflect his political concerns in The Scarlet Letter? Or better to say, what strategies does he use to show the deficits of a dogmatic religious colony and the necessity of liberty or republicanism? Many strategies can be mentioned, but some of them seem to be of more significance: The insertion of "the Custom House","mentioning Ann Hutchinson", "the archaic language", and finally"the magical religious implications". Each of these elements will be discussed below:

As it was mentioned at the beginning, "the Custom House" is the semi-autobiographical section, preliminary to Hawthorne's The Scarlet Letter. In this section he describes the gloomy years in which his political struggles caused him to be fired from his job and sent to Salem, his native land to a chore in a custom house-in order to afford his family financially. In this sectionhe explains his daily job and speaks about those people who worked there. It is too interesting that he explicitly expresses his dislike for them who were all "Whigs" ("Hawthorne 13), and opposite with him in political interests. But the most important matter to add is what Hawthorneexpresses about the way working there affected him: "It was time, at length, that I should exercise other faculties of my nature, and nourish myself with food for which I had hitherto had little appetite" (25).In fact, this is that boring context- being again in his native land associated with the shameful memory of his puritan forefathers-that makes Hawthorne to think of matters which he had never had enough time to think of; and much spare time which out of boredom sent him finally to that old mansion of the office among those ancient documents resulting in finding that Scarlet Letter.

To speak about the second strategy first of all another matter should be discussed. One of the strategies of Hawthorne in this novel is to use some factual characters and data- as he found them in that office in the custom houseand to give himself "as much license as if the fact has been entirely of [his] own invention"(33),in order to give authenticity to his writing and to manipulate the plot in line with his own political interests. One of the key strategies of him is speaking about Ann Hutchinson in the first chapter and equating her captivation with that of Hester Prynne as he mentions her to enter the same prison door- where once Ann Hutchison had trodden in. Ann Hutchinson was a woman whose struggle for establishing a new religious sect in a patriarch puritan context-that would consider women to a large extend as sinners or witches- will lead to her captivation at prison and finally her execution. According to an article byMichael J. Colacurcio, in Hawthorne's mind Ann Hutchinson's "Spiritual Freedom" is identical with Hester Prynne's struggle for sexual freedom. For more elaboration Colacurcio adds that Hawthorne's main concern is to criticize the treatment of a government with restricted religious rules and laws dictated to the citizens- especially to the women to a greater extend- in order to bring a proof to the fact that lack of liberty and republicanism will result in injustice on the side of government and moral religious aversion on the side of people (460). That is why the reader finally finds that after seven years of bearing the token of sin, the scarlet letter-once a disaster for Hester- becomes "the objectof love and interest" (Hawthorne262), and at least an stimuli for the people of that colony to ask themselves these questions: Is Hester Prynne a victim of the false social rules of conduct? Is not her sin the result of the religious teachings that Arthur Dimmesdale had once felt himself to be the defender of? And does not this show a deficit in their societal religious and moral philosophy that a woman once a sinner is regarded as a saint? 
Another strategy to be discussed here is the archaic language of the novel. It may be claimed that for Hawthorne using such a language is only a way of bring his language in line with the historical context of the occurrence of the events of the novel, but it seems that in such a complicated work of literature, such a writer must have been of more thought or intention in applying that kind of language. By this archaic use of language he is even going beyond the language of the sixteenth century in New England and is somehow close in diction and syntax to the first English translations of Bible. In such colonies that religion is to rule dogmatically over all aspects of people's life, it cannot leave the language of people unaffected. And as language is the faculty which shapes one's reflection and thought, it cannot be neglected by Hawthorne in the process of writing. He intends to criticize the superficiality of thought in people of such colonies and reflect what the lack of liberation of thought would bring about; that is why he represents people speaking in the likeness of holly Bible in all its allusiveness, while being actually null and frivolous. A good example of such a language could be found in the part when one of the people of the town answers Chillingworth's question about what Hester has committed:

\begin{abstract}
'Of a truth, friend, that matter remaineth a riddle; and the Daniel who shall expound it is yet a-wanting', answered the townsman. Madame Hester absolutely refuseth to speak, and the magistrates have laid their heads together in vain.Per-adventure the guilty one stands looking on at this sad spectacle, unknown of man, and forgetting that God sees him.' (62)
\end{abstract}

The last matter to talk about is the way religious elements or ordinary things behold in the light of religion, show themselves in the novel and help Hawthornestrengthen his intended theme, that is to question the dogmas of such societies under the rules of religion and their interpolation of ideologieswhich holds people from looking consciously at the facts of their life. Someproofs from the text can be helpful in elaborating the issue:

1. Hester Prynne has accepted to bear the punishment alone as she finds it forbidden to shake Arthur Dimesdale's religious dignity and reputation.

2. Hester is even in doubt about Pearl's essence and even though she adores her infinitely, sometimes she looks at her with awe and finds her daughterthe live punishment on herself; that is why she expresses the fact that if it was not for the sake of this punishment- fatalism- she would accept Mistress Hibbin's offering for joining Blackman's Party- Satan's Community- at night.

3. Pearl is always pictured as a supernatural creature who is very sensitive about the Scarlet Letter on her mother's bosom. Her repartee in presence of the holly magistrates and Arthur Dimmesdale also makes everyone dazzled.

4. Even Dimmesdale titles Pearl the "elfin child" that is not to cross the brook, when he has reunited with Hester in the forest after seven years.

5. People would interpret the "A" in meteor not to stand for Dimmesdale's sin and his glove found on the scaffold after that night of vigil by a Sexton is inferred to be taken there by the mischievous Satan who would always be in struggle to ruin men of God.

6. Dimmesdale's confession at the ceremony is interpreted metaphorically and people would never accept that he was the one who had to be punished as the other culprit beside Hester.

Having investigated someexamples from the text as the proof to Hawthorne's strategies for the development of the thematic structure of his novel, at the final stage it should be reminded thatbecause of his puritan ancestry as well as his political concerns, Hawthorneis to criticizethe basis of American civil life and to look at the matter of liberty-from republican point of view- with too much skepticism and doubt; that is why even at the end the reader is unable to draw a conclusion about Hester's case and cannot give an answer to the question that whether she is finally able to reach enough consciousness about her condition or she just passes away with an illusion of liberation of herself from social restriction- resting with a careful distance from Arthur Dimmesdale's grave. Maybe the answer is to be found where "On A Field, Sable, The Letter A Gules".

\title{
References
}

Colacurcio, Michael J. "Footsteps of Ann Hutchinson: The Context of the Scarlet Letter".

ELH, Vol. 39, No. 3 (Sep., 1972), pp. 459-494

Gussman, Deborah. "Fictions of Political Identity in 'Hobomok' and The Scarlet Letter. 
College Literature, Vol. 22, No. 2 (Jun., 1995), pp. 58-80 Hawthornee, Nathaniel. The Scarlet Letter. 2nd ed. Oxford: Oxford University Press, 1990.

Patrick Moss, Andrew. The Cultural Constitution Of The Post-Republic: Eighteenthcentury Politics And Nineteenth-Century Literary Form .Diss. University of Illinois at Urbana-Champaign: Urbana, Illinois 2010.

Reynold, Larry J. "The Scarlet Letter and Revolutions Abroad".American Literature, Vol. 57, No. 1(Mar., 1985), pp. 44-67 